\title{
QUALITY OF EDUCATION AND SUSTAINABLE DEVELOPMENT GOALS IN PAURI GARHWAL
}

\author{
P.D. SINGH, A. S. MANHAS AND S. GUSAIN
}

Department of Economics, Hemvati Nandan Bahuguna Garhwal University Srinagar Garhawl, Uttarakhand-246174

*Corresponding Author Email: pawanmanhas@ mail.com

Received: 12.9.2020; Revised: 26.11.2020; Accepted: 21.12.2020

(O) Society for Himalayan Action Research and Development

\begin{abstract}
Education is that thread which ties the society with the discipline and knowledge. Role of education is experienced universally which transforms societies in a fastidious way and leading to the sustainable development. It is essential to development of any nation. It is the backbone of development and is critical for improving the ability of the human beings to handle environmental and development issues for which basic education is a foundation of environmental knowledge and higher education needs to be integrated as an important part of learning. Education sustains the human values which contribute to individual and collective well-being. Education can enhance the effectiveness of each policy instrument by developing information engagement, agency and empowerment among all affected stakeholders. Education can build a drastic change that is sustainable change because it is created by the learner and reaches hearts and minds. Education can also sustain different human values that can collectively contribute to well beings of individuals and the society. It is the basis for increasing confidence for facing challenges and lifelong learning deeds that can achieve every goal of the individual building. The definition of quality education is different from person to person. There are many important factors responsible for quality of education for example teacher pupil ratio, infrastructure of the school, expenditure of the school on various teaching aids and projects, etc. Major problems of quality education are; limited policy relevant knowledge, policies related to quality education are not based on thorough research, Absence of standardized outcome measures and absence of highly skilled researchers and research capacity in general.

Present study is supposed to focus on quality parameters of education that can help achieve goal 4 of sustainable development goals therefore the purpose of this study is to give a brief review of quality parameters of education and status of sustainable development goals in Pauri Garhwal district of Uttarakhand.
\end{abstract}

Keywords: SDGs, TPR, GER, Quality of Education, Public expenditure on Education, Student Retention Rate.

\section{Introduction}

Education which is considered as backbone of the society is the base of human as well as economic development. Taking serious concerns and importance of education for the society, government of India declared Right to Education as a fundamental right by enforcing RTE act of 2009. According to this act every child has a fundamental right to access free and compulsory education from 6 years to 16 years of age. Government of India is implementing various schemes such as SSA, RMSA etc. to make education easily accessible for every child in the society. Education is an enlightening experience which helps in 
making a meaning out of the complex realities of life. Nobel laureate Amrtya Sen considered the education and health as two vital elements for the realization of full potential of individuals and nations. The role of education in facilitating social and economic progress has long been recognized. Education improves functional and analytical ability and thereby opens up opportunities for individuals and also groups to achieve greater access to labour markets and livelihood.

\section{Statement of the Problem}

Major problems restricting quality of education are; limited policy relevant knowledge base, policies not based on thorough research, absence of standardized outcome measure, absence of highly skilled researchers and research capacity in general. There is high dropout, low retention rate, low enrolment in schools, and low access of education to all. To provide high level of qualitative education to all sections of society is vital problem. Considering the importance of the concept this problem is taken for the study. The problem under investigation is entitled "Quality of Education and Sustainable Development Goals Pauri Garhwal".

\section{Importance of the study}

Education is vital human right and plays a key role in human, social and economic development. Present study will help to draw standardized measures and formulate important policies for the improvement of the quality education in the study area as well as in the whole state of Uttarakhand. Study will also contribute as a literature for further study.

\section{Objectives of Study}

Present study is supposed to focus on quality parameters of education that can help achieve goal 4 of sustainable development goals therefore the objective of the study is to evaluate the status of quality of education in Pauri Garhwal

\section{Methods and Procedures}

Present study tries to find the status of quality education in Uttarakhand particularly in Pauri district and analysis the role of quality education in developing the SDGs index. We have taken several factors that contribute to quality of education like Teacher Pupil Ratio, Net Enrolment Rate, Students learning outcome, Dropout rate etc. to find out the status of quality education in Pauri district of Uttarakhand. Secondary data from 2010 is considered to get the desired results for the study.

\section{Delimitations}

This study will limit its scope to Pauri district of Uttarakhand. The information used in this study will be restricted to those gathered from 2010. Although the limitations in the collection or use of data 
acknowledged in this study, it will not counsel the changes to the compilation, assessment or treatment of existing or upcoming statistical data.

\section{Review of Literature}

A number of research studies have been conducted on various aspects of the study. However, literature based on micro-level evaluation studies relating directly or indirectly to the subject matter of the present study is scanty. A few prominent studies are reviewed in the following paragraphs:

Bruns et.al. (2019) Surveyed academic literature on the politics of reforms and a wide range of empirical research on reform experiences across the world. Study emphasized recent reforms in Latin Africa. Main focus of the study was on teacher policy reforms. Study concluded that academic researchers have largely neglected the politics of education reform and left a gap in knowledge base. Filho et.al (2018a) Reviewed sustainable development goals for the understanding of sustainability challenges. Study also presents five case studies to show how best the SDGs can be handled in practice. Main purpose of the study is to explore the linking process between the SDGs and the need to provide a better understanding of the current and emerging challenges in respect to sustainable development. Study found that the process of implementation of SDGs offers unrivalled opportunities, as well as many challenges which are important to be met in advancing equal opportunities and fostering economic empowerment which could help countries to promote the cause of sustainable development in their territories and hence benefiting the people living in these countries.

Filho et.al (2018b) presents an outline of the process leading to the agreement on the SDGs based on the proposals, methods, models or criteria debated by the focus group which consists of eight experts of different countries to reinvigorate the research agenda and highlighting the role of sociological dimension connected holistically with the SDG. Present study was aimed to look at the implementation of the SDGs and to delineate a set of research needs. Study also discussed the importance of some measures and paths to explore and explain why the UN SGDs need to be accorded greater priority in international sustainable development research efforts. Volosovets et.al. (2017) evaluated the quality of education at Russian preschool educational institutions in a study taking duration of four years. Three major areas where the study focused were favourable environment at a pre-school educational institution facilitating the development of a child, professional qualifications of teachers working with children and extra services provided by a kindergarten. Within the four year framework permanent mechanism was designed for evaluating the quality of kindergartens.

Bazhenov et.al. (2015) analysed the components of monitoring as one of management tools for the higher education system at macro and micro levels. The main purpose of the study was to identify the problems of its organization and implementation in the system of professional education. Study found that insufficient account has been taken of opportunities emerging from their direct impact on the effectiveness of education quality. Lisievici (2015) hypothesized that the quality of education construct used in the design and management of the quality assurance system led to its ineffectiveness and additional negative side-effects on the whole education. Study found that unforeseen negative consequences outlined in current quality assurance system was due to the conceptual foundations of the system which cannot stand scientific scrutiny. Yiu \& Saner (2014) analysis the scope of the sustainable development goals after the end of millennium development goals. 
Authors provided theoretical analysis of MDMs and SDGs. Post 2015(when millennium development goals ended) development agenda and MDGs are also described. Study found that although many new developments are arising from negotiations still some discrepancies exists in the discourse.

\section{Results and Discussion}

First step in the process of education development is universalisation of education and the next step is quality improvements in every level of education. India is almost successful in achieving the goal of universalisation of education but we are far behind in terms of qualitative improvements. Quality education provides children with basic cognitive and language skill and fosters emotional development. Globally we are experiencing an important role of education in the development of the society in a particular way which leads to the sustainable development of the world. Education is a valuable resource of addressing structural inequalities and disadvantages (Singh et. al., 2018). Education plays an important role for the sustainable development of the nation by providing skilled and technically sound generation. Education is the backbone of development and it is critical for promoting sustainable development and improving the ability of the human beings to handle environmental and development issues for which basic education is a foundation of environmental knowledge.

The role of education in social mobilization is very significant at the present time, especially in developing countries. For, modern society is passing through an age which demands good performance for the fulfillment of its requirements. Education helps in this task. The state is known for its centers of high quality schooling, much higher than most of the other states in India. But condition of the government schools is hopeless. Education is essential to the success of every one of the 17 sustainable development goals framed by United Nations in 2015. It helps to eradicate poverty, improves nutrition of a child via educated mother, educated people are less vulnerable to health problems, education eradicates gender inequality, improves quality of education itself, improves income inequalities, education leads to economic growth and prosperity, it helps to improve sanitation facilities, with the higher level of education people across many different societies show greater concern about the wellbeing of the environment, etc. in fact every aspect of prosperity and development is concerned to education. It is the critical component which contributes to human capital that is important for sustainable development.

Education is a critical component which contributes extensively in the human development indices. It is one of the most important ways to attain the goal of sustainable global development. Educational development has had deep impact on social relations having significant political implications. Its consequences may be seen through the changing pattern of relationship between the few very rich and the large many poor people, between the educated and undereducated between the upper and the lower castes, and more especially between the older and younger generations. Widespread debate about education within the post-2015 development arena has taken place in the run up to 2015 and continues today - most recently in the form of the Incheon Declaration which was the outcome of the 2015 UNESCO World Education Forum (Strydom and Okkolin, 2016). 


\section{Sustainable Development Goals and Quality of Education}

Education is widely acknowledged as a basic human right and a critical prerequisite for successful contemporary democracy and for thriving, sustainable, and just economies and societies (Marshall, 2018). The UN SDG global indicator framework includes 244 indicators across its 17 goals and 169 targets (Corti et.al. 2019) that replaced the earlier MDGs in September 2015 explicitly include the quality perspective and aim for: "inclusive and equitable quality education" -Goal 4 (Birchler and Michaelowa, 2015) are an inter- governmental set of aspiration Goals with 169 targets post Millennium Development Goals (MDGs) to transform our world. The Sustainable Development Goals were developed as a followup to the Millennium Development Goals and adopted by the UN General Assembly in September 2015. The UN (2015) document launched the global 2030 agenda for Sustainable Development which aims to stimulate action over the next 15 years in areas of critical importance for humanity and the planet (Dlouhá and Prospišilová, 2017). Well defined evaluation with proper time frame, by a credible agency/individual using appropriate resources and approach is essential. A standardized evaluation process will ensure utilization of findings, as well and take corrective measures, if needed in the programs and schemes, to ensure achieving the 17 SDGs (Srivastava, 2018). In today's world the importance of education as a crucial factor in the formation of a new quality of economy and society is increasing with the growth of the influence of human capital (Bazhenova et al., 2015) and Sustainable Development Goals framework calls for universal primary and secondary education that leads to relevant and effective learning outcomes- SDG (Languille, 2019).

The quality of education of a particular individual determines not only the level of his/her life, but also that of his/her family members, colleagues and others interacting with him/her (Bazhenova et.al., op.cit) and SDG 4 vows to "ensure inclusive and equitable quality education" for all students (Bruns et.al.,2019).

\section{Indicators responsible for Quality of Education in the Study Area}

To measure the performance of Pauri Garhwal towards Quality Education five indicators have been identified. These indicators have been selected based on availability of data at the district level.

Net Enrolment Ratio: Net enrolment rate is the number of students in the theoretical age group for a given level of education which is calculated by dividing the number of students enrolled in the official age group for a given education by the population for the same age group and multiplies the result by 100. 
Table and Figure 1: Net Enrolment Ratio

\begin{tabular}{|l|l|l|}
\hline \multirow{2}{*}{ Year } & Net Enrolment Ratio \\
\cline { 2 - 3 } & Primary & Upper Primary \\
\hline $2010-11$ & 74.5 & 75.3 \\
\hline $2011-12$ & NA & NA \\
\hline $2012-13$ & 81.7 & 70.4 \\
\hline $2013-14$ & 88.6 & 73.9 \\
\hline $2014-15$ & 84.86 & 73.78 \\
\hline $2015-16$ & 82.87 & 78.62 \\
\hline $2016-17$ & 79.04 & 74.19 \\
\hline
\end{tabular}

Source: Compiled from DISE data, Note: data for2011-12 was not applicable, N.A.- Not applicable

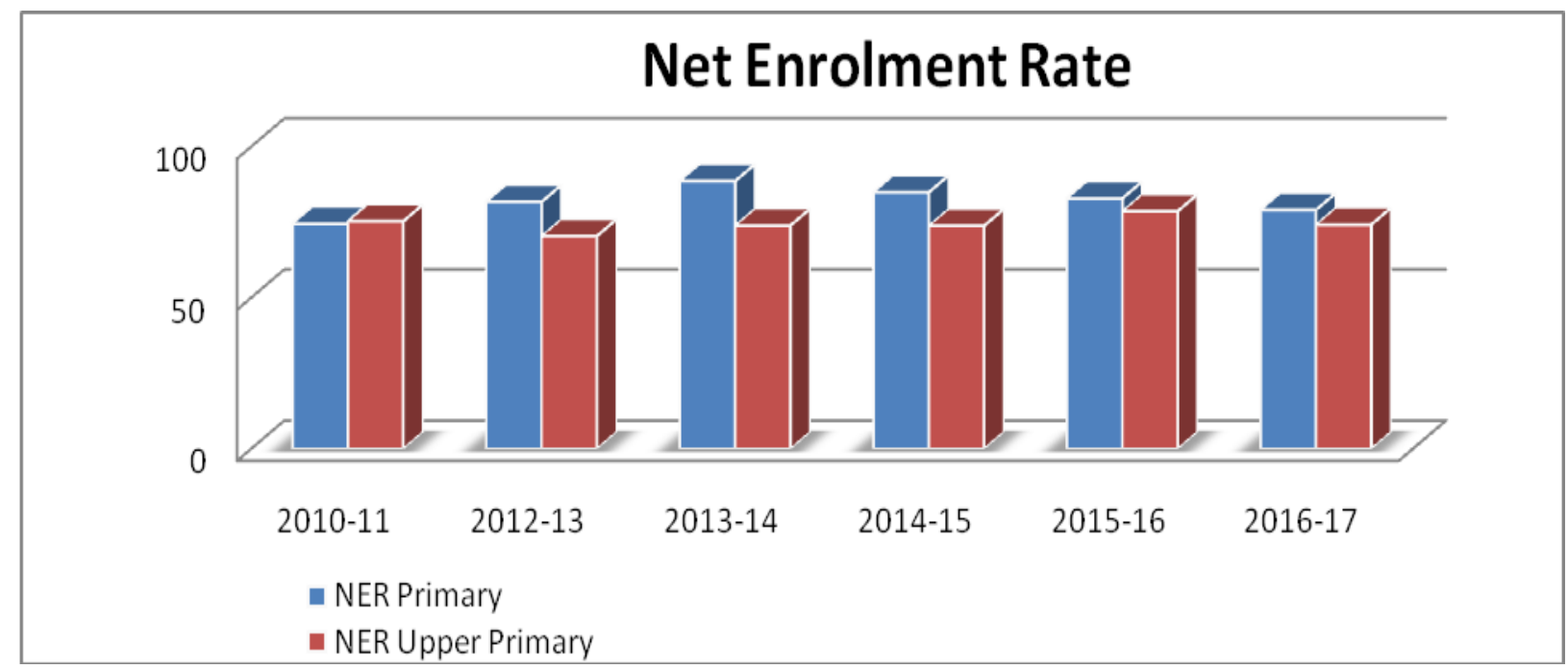

From Table and Figure 1, it can be understood that NER is decreasing from last three years which is a cause of concern. From above figure it is clear that in 2010-11 NER was 74.5 percent for primary education and 75.3 percent for upper primary education which increased to 88.6 percent in 2013-14 for primary and 78.62 in 2015-16 for upper primary education. But in 2015-16 NER decreased marginally to 79.04 percent for primary and 74.19 percent for upper primary education.

\section{Learning Outcomes}

Learning outcomes are statements that describe the knowledge or skills students should acquire by the end of a particular assignment. This indicator plays very important role in quality education, to improve the quality of education we have to improve learning outcomes of the students. 
Table 2: Learning outcomes for $5^{\text {th }}$ class

\begin{tabular}{|l|l|l|l|l|l|l|l|l|l|l|l|l|}
\hline Subject & \multirow{2}{*}{ Overall } & \multicolumn{2}{|c|}{ Gender } & \multicolumn{2}{|c|}{ Area } & \multicolumn{2}{|c|}{ Management } & \multicolumn{4}{|c|}{ Social Groups } \\
\cline { 3 - 11 } & & Male & Female & Rural & Urban & Govt. & Aided & Sc & ST & OBC & GEN \\
\hline Mathematics & 66.51 & 65.43 & 67.55 & 66.33 & 67.58 & 66.96 & 34.29 & 68.50 & 81.54 & 70.22 & 64.92 \\
& & & & & & & & & & & \\
\hline Language & 71.82 & 69.77 & 73.77 & 70.97 & 76.80 & 71.83 & 70.48 & 72.02 & 79.49 & 78.22 & 71.14 \\
\hline EVS & 69.52 & 67.88 & 71.09 & 69.43 & 70.05 & 69.79 & 50.48 & 72.21 & 76.41 & 72.44 & 67.98 \\
\hline
\end{tabular}

Source: Compiled from National Achievement Survey, NCERT, 2017

Table 3: Learning outcomes for $8^{\text {th }}$ class

\begin{tabular}{|l|l|l|l|l|l|l|l|l|l|l|l|l|}
\hline Subject & Overall & \multicolumn{2}{l|}{ Gender } & \multicolumn{4}{l|}{ Area } & \multicolumn{4}{l|}{ Management } & \multicolumn{3}{l|}{ Social Groups } \\
\cline { 3 - 12 } & & Male & Female & Rural & Urban & Govt. & Aided & Sc & ST & OBC & GEN \\
\hline Mathematics & 45.71 & 46.50 & 44.96 & 44.24 & 63.29 & 44.66 & 49.01 & 41.38 & 20.01 & 56.31 & 46.77 \\
\hline Language & 66.99 & 66.16 & 67.79 & 66.08 & 77.78 & 66.93 & 67.16 & 61.27 & 73.33 & 67.23 & 69.41 \\
\hline Science & 53.93 & 53.20 & 54.63 & 52.78 & 67.54 & 52.83 & 57.35 & 51.30 & 46.67 & 55.32 & 54.95 \\
\hline $\begin{array}{l}\text { Social } \\
\text { Science }\end{array}$ & 54.25 & 55.53 & 53.01 & 53.64 & 61.45 & 54.80 & 52.53 & 50.79 & 33.33 & 59.72 & 55.33 \\
\hline
\end{tabular}

Source: Compiled from National Achievement Survey, NCERT, 2017

Learning outcomes for class $5^{\text {th }}$ is represented in Table 2 and for class $8^{\text {th }}$ in Table 3 according to gender, management, area and social groups. National Achievement Survey conducted by NCERT in 2017 found learning outcomes of $5^{\text {th }}$ and $8^{\text {th }}$ standard in different subjects very poor. It was 66.51 percent in mathematics, 71.82 percent in Language, 69.52 percent in EVS for students of $5^{\text {th }}$ standard and 45.71 percent in Mathematics, 66.99 in Language, 53.93 percent in Science, 54.25 percent in SST for students of $8^{\text {th }}$ standard. Learning outcomes along with other factors play an important role in quality of education.

\section{Average Annual Dropout at Primary level}

Dropout is the proportion of pupils from cohort enrolled in a given grade at a given school year who are no longer enrolled in the following school year. It is calculated by subtracting the sum of promotion rate and repetition rate from 100 . 
Table and Figure 4: Average annual Drop-out at Primary level.

\begin{tabular}{|l|l|}
\hline Year & Drop-out \\
\hline $2010-11$ & 2.2 \\
\hline $2011-12$ & 6.6 \\
\hline $2012-13$ & 4.9 \\
\hline $2013-14$ & 4.4 \\
\hline $2014-15$ & 4.02 \\
\hline $2015-16$ & 5.20 \\
\hline $2016-17$ & 3.18 \\
\hline
\end{tabular}

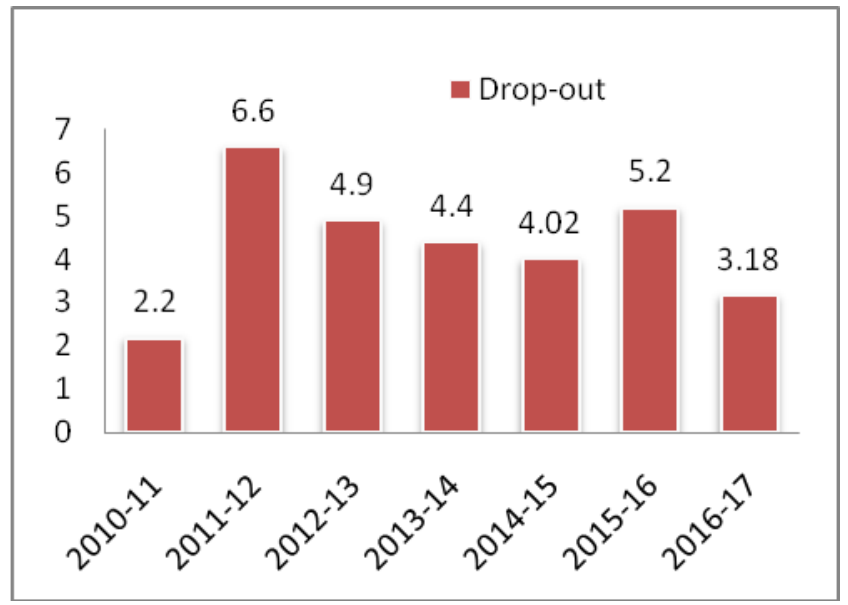

Source: Compiled from DISE data

It is clear from above Table and Figure 4 that there is a great fluctuation in drop out ratio of primary school students. In 2010-11 it was 2.2 percent then it jumped to 6.6 percent in 2011-12, than it marginally decreased till 2015-16 when dropout ratio increased to 5.20 percent and finally in 2016-17 it again decreased to 3.18 percent. It could be noted here that there is decreasing trend in dropout ratio within the period of investigation.

\section{Professionally Qualified Teachers}

Qualified teachers are the key to quality education. However according to the UNESCO institute of Statistics, in 31 of the 96 countries with data, less than 80 percent of primary school teachers were reportedly trained according to national standards in $2014^{1}$. Professionally qualified teachers are those teachers who are bearing minimum education requirement of a teacher along with professional training and higher education qualifications.

Table and Figure 5 represents professionally qualified teachers on the basis of their appointment. If we look on the trend of qualified teachers it is clear that there is increasing trend in both the categories starting from 2010-11 we can see percentage of qualified teachers increasing year after year till 2015-16. It was 93.6 percent under regular category in 2010-11 which increased to 96.8 percent in 2015-16 showing marginal increase in all years except 2012-13 when it decreased to 82.7 percent from 92.0 percent in previous year. Growth in the qualification of contractual teachers increased to a great extent from 19.9 percent in 2010-11 to 75.9 percent in 2015-16. Overall we can say there is great improvement in number of qualified teachers in the study area.

\footnotetext{
${ }^{1}$ The need for more professionally qualified teachers (2017), available at https://en.unesco.org/news/need-moreprofessionally-qualified-teachers
} 
Table and Figure 5: Professionally Qualified teachers

\begin{tabular}{|l|l|l|}
\hline \multirow{2}{*}{ Year } & \multicolumn{2}{|l|}{ Professionally Qualified Teacher } \\
\cline { 2 - 3 } & Regular & Contractual \\
\hline $2010-11$ & 93.6 & 19.9 \\
\hline $2011-12$ & 92.0 & 25.3 \\
\hline $2012-13$ & 82.7 & 27.4 \\
\hline $2013-14$ & 92.0 & 43.8 \\
\hline $2014-15$ & 95.7 & 72.2 \\
\hline $2015-16$ & 96.8 & 75.9 \\
\hline
\end{tabular}

Professionally Qualified Teachers

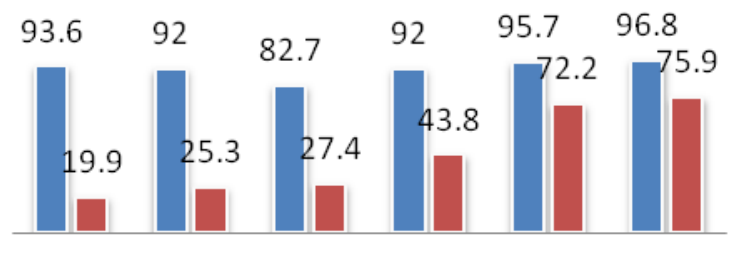

2010-112011-122012-132013-142014-152015-16

- Professionally Qualified Teacher Regular

- Professionally Qualified Teacher Contractual

Source: Compiled from DISE data

\section{Pupil- Teacher Ratio}

Pupil Teacher Ratio is the average number of pupils per teacher at a given level of education based on the headcounts of both pupils and teachers calculated by dividing the total number of pupils enrolled at the specified level of education by the number of teachers at the same level. Prescribed PTR is 30 at primary and 35 at upper primary level. Pupil- teacher ratio in the study area compiled from the DISE data is shown in above table 3.2.5.1 and chart. There is a fall in PTR in both primary and upper primary schools in the study are due to the shortage of teachers. Following table will present percentage of schools with required PTR and SCR.

Table and Fig 6: Pupil -Teacher Ratio at Primary and Upper Primary Schools

\begin{tabular}{|l|l|l|}
\hline \multirow{2}{*}{ Years } & \multicolumn{2}{|l|}{ Pupil -Teacher Ratio } \\
\cline { 2 - 3 } & Primary & Upper Primary \\
\hline $2010-11$ & 16 & 51 \\
\hline $2011-12$ & 16 & 34 \\
\hline $2012-13$ & 14 & 44 \\
\hline $2013-14$ & 13 & 25 \\
\hline $2014-15$ & 11 & 20 \\
\hline $2015-16$ & 10 & 16 \\
\hline $2016-17$ & 10 & 15 \\
\hline
\end{tabular}

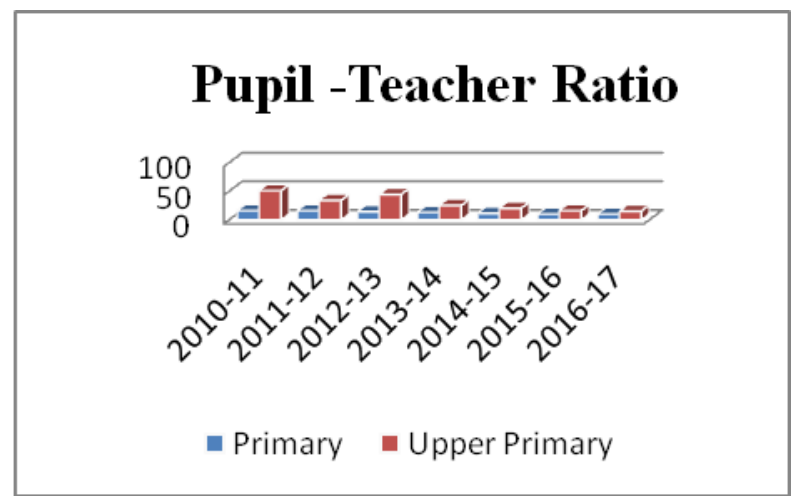

Source: Compiled from DISE data

Percentage of schools which fulfills the criteria of Pupil Teacher Ratio (PTR) and School Classroom Ratio (SCR) is shown in Table 7. Pupil Teacher Ratio at primary level is 30 students per teacher and at upper primary level it is 35 students per teacher. According to DISE data it is shown that percentage of schools with required PTR is decreasing from 13.7 percent in 2010-11 to 2.29 percent in 2015-16 at Primary level and 12.8 percent in $2010-11$ to 5.57 in $2015-16$ at upper primary level. Same is the 
condition of SCR at primary level in study area, it shows decreasing trend from 4.6 percent in 2010-11 to 2.09 percent in 2015-16. Only SCR at upper primary level is showing marginal increase from 4.9 percent in 2010-11 to 5.10 percent in 2015-16.

Table 7: Percentage of Schools with PTR and SCR

\begin{tabular}{|l|l|l|l|l|}
\hline \multirow{2}{*}{ Years } & \multicolumn{2}{|l|}{ Percentage of Schools with PTR } & \multicolumn{2}{l|}{ Percentage of Schools with SCR } \\
\cline { 2 - 5 } & Primary/30 & Upper Primary/35 & Primary/30 & Upper Primary/35 \\
\hline $2010-11$ & 13.7 & 12.8 & 4.6 & 4.9 \\
\hline $2011-12$ & 11.8 & 8.5 & 3.5 & 2.4 \\
\hline $2012-13$ & 8.41 & 5.70 & 3.39 & 5.23 \\
\hline $2013-14$ & 4.68 & 5.16 & 3.40 & 6.81 \\
\hline $2014-15$ & 3.50 & 9.24 & 2.64 & 5.31 \\
\hline $2015-16$ & 2.29 & 5.57 & 2.09 & 5.10 \\
\hline
\end{tabular}

Source: Compiled from DISE data

\section{Conclusion and Implications of The Study}

In September 2015, the United Nations General Assembly formally adopted the "universal, integrated and transformative" 2030 Agenda for Sustainable Development, a set of 17 Sustainable Development Goals SDGs (Srivastava, 2018) and Goal 4 of SDGs is dedicated to quality education. We have taken five important factors which are responsible for quality of education and play very important role in the growth of quality education. Data collected and compiled from DISE and NAS is used to study the status of quality education in the study area. Although there is decrease in PTR and fluctuation in NER but there is also a growth of professionally qualified teachers and decreasing dropout rate making district one among highest learning districts. Study found that these five factors are very much responsible for the growth of goal 4 of SDGs. According to SDG India index baseline report 2018 conducted by NITI Aayog ranks Uttarakhand at $9^{\text {th }}$ rank in SDGs goal 4 Index. Study is concluded with the outcomes of these factors representing growth of quality indicators in the study area. Present study can be helpful to develop a working model by considering these factors at district level as well as at state level.

\section{Scope of Further study}

Study was limited its scope Pauri Garhwal district due to time constraint; however this can be increased to other districts. Only five factors are taken for the study which can also be increased to more than five. Research is a continues process so this research can further be improved by refining and injecting different factors of quality education and also this study can be extended to other goals of SDGs. 


\section{References}

Bazhenov R, Bazhenova N, Khilchenko L \& Romanova M (2015): Components of Education Quality Monitoring: Problems and Prospects, Procedia-Social and Behavioral Sciences 214: 103-111 (doi:https://doi.org/10.1016/j.sbspro.2015.11.600 )

Birchler K, \& Michaelowa K, (2015): Making aid work for education in developing countries: An analysis of aid effectiveness for primary education coverage and quality, International Journal of Education Development (doi:https://doi.org/10.1016/j.ijedudev.2015.11.008)

Bruns B, Macdonald I.H \& Schneider B (2019): The politics of quality reforms and the challenges for SDGs in education. World Development: 118,27-29

(doi:https://doi.org/10.1016/j.worlddev.2019.02.008)

Corti BG, Lowe M \& Arundel J (2019): Achieving the SDGs: Evaluating indicators to be used to benchmark and monitor progress towards creating healthy and sustainable cities, Health Policy, (doi:https://doi.org/10.1016/j.healthpol.2019.03.001)

Dlouhá J and Prospišilová M (2017): Education for Sustainable Development Goals in public debate: The importance of participatory research in reflecting and supporting the consultation process in developing a vision for Czech education. Journal of Cleaner Production, (doi:https://doi.org/10.1016/j.jclepro.2017.06.145)

Filho W.L. Tripathi, S. K., Andrade Guerra, J. B. S. O. D., Giné-Garriga, R., OrlovicLovren, V., \& Willats, J. (2018a): Using Sustainable Development Goals towards a better understanding of Sustainability Challenges, International Journal of Sustainable Development \& World Ecology. vol.26 (2), pp.179-190

Filho, W.L., Azeiteiro, U., Alves, F., Pace, P., Mifsud, M., Brandli, L., et al. (2018). Reinvigorating the sustainable development research agenda: The role of the sustainable development goals (SDG).International Journal of Sustainable Development and World Ecology,25(2), 131142. https://doi.org/10.1080/13504509.2017.1342103

Languille S (2019): The politics of the education budget: Financing mass secondary education in Tanzania (2004-2012). International Journal of Educational Development: 66,: 96-104, (doi:https://doi.org/10.1016/j.ijedudev.2019.02.003)

Lisievici P (2015): The forgotten side of quality: Quality of education construct impact on quality assurance system, Procedia-Social and Behavioral Sciences : 180 : 371-374

Marshall K (2018): Global education challenges: Exploring religious dimensions, International Journal of Educational Development, :62:184-191, (doi:https://doi.org/10.1016/j.ijedudev.2018.04.005)

Singh PD, Manhas AS and Salgotra AS (2018). Status of Education and Rural Development in Himalayan State Uttarakhand of India. International Journal of Innovative Knowledge concepts, 6(1): 14 (doi: http//:11.25835/IJIK-224 www.doie.org)

Srivastava, A., (2018): Standardizing Evaluation Process: Necessary for Achieving SDGs - A case study of India, Evaluation and Program Planning, vol.69, pp.118-124 doi: https://doi.org/10.1016/j.evalprogplan.2018.05.001

Strydom MW and Okkolin MA (2016): Enabling environments for equity, access and quality education post- 2015: Lessons from South Africa and Tanzania. International Journal of Education Development, : 49, : 225-233 (doi: https://doi.org/10.1016/j.ijedudev.2016.03.010 ) 
Volosovets T, Kirillov I, Buyanov A (2017): Evaluating the quality of preschool education in Russia, Procedia-Social and Behavioral Sciences :237:1299-1303 (doi:https://doi.org/10.1016/j.sbspro.2017.02.213 )

Yiu LS, Saner R (2014): Sustainable Development Goals and Millennium Development Goals: An analysis of the shaping and negotiations process, Asia Pacefic Journal of Public Administration, 36(2), 89-107

http://uis.unesco.org/en/glossary-term/dropout-rate-grade

http://uis.unesco.org/en/glossary-term/net-enrolment-rate

https://ourworldindata.org/global-rise-of-education;

http://udise.in/

http://www.ncert.nic.in/programmes/NAS/DRC.html

http://www.asercentre.org/

https://teaching.utoronto.ca/teaching-support/course-design/developing-learning-outcomes/what-are-

learning-outcomes/ 